\title{
The Effectiveness of Ozone Therapy in the Patient with Necrotic Vasculitis Wound
}

\author{
Hayriye Alp* \\ Necmettin Erbakan University, Getat Center, Turkey \\ *Corresponding author: Hayriye Alp, Necmettin Erbakan University, Getat Center, Konya, Turkey
}

\begin{tabular}{|c|c|}
\hline ARTICLE INFO & ABSTRACT \\
\hline Received: 㓞 January 23, 2021 & $\begin{array}{l}\text { Necrotic wounds are common injuries in many patients hospitalized in intensive } \\
\text { care. Ozone therapy has been used as a complement to modern medicine since } 1902 \text { in }\end{array}$ \\
\hline Published: 蔧 February 03, 2021 & the treatment of diabetes. It has been used in our country since 1999. With ozone therapy \\
\hline tation: Hayriye Alp. The Effec & $\begin{array}{l}\text { the venous part. Ozone therapy has been shown to reduce proinflammatory cytokines in } \\
\text { soft tissue infections. This method of treatment will provide significant benefits if used in } \\
\text { addition to modern medicine. }\end{array}$ \\
\hline
\end{tabular}

Vasculitis Wound. Biomed J Sci \& Tech Res 33(4)-2021. BJSTR. MS.ID.005432.

Keywords: Necrotic Wound; Ozone Therapy; Antiphospholipid Syndrome

\section{Introduction}

With the effect of ozone bradykinin release and inflammation inhibition of prostaglandin synthesis, it has an analgesic effect. It increases the release of antagonists that neutralize proinflammatory cytokines such as ozone IL-1,8,12,15 and TNF. Depending on the stage and location of the lesion, ozone gas is used in concentrations of $60-40-30-20 \mu \mathrm{g} / \mathrm{ml}$ in periods of 20-30 minutes. In purulent infections, 60-70 $\mu \mathrm{g} / \mathrm{ml}$ can be used. After the infection is under control and healthy granulation tissue is seen, the dose and session interval can be reduced. Erythrocytes increase elasticity and deformability, blood can circulate better in microcirculation, tissue oxygenation increases. Ozone therapy used in soft tissue infections has been shown to significantly reduce pro inflammatory cytokines $($ IL-6,8,10) and fibroblast growth factor levels [1].

The effect of ozone therapy on necrotic wounds. This technique made with ozone therapy is considered as one of the best methods on the human body that you can do both for aesthetic treatment and for the treatment of diseases (Figure 1). It provides the opportunity to treat the person in a comfortable environment without any side effects, using a non-invasive method. Ozone oil is obtained by passing the ozone bubbles obtained from pure oxygen through olive oil (sunflower oil, etc.) for a certain period of time. Double bonds of unsaturated fatty acids in oils such as olive oil are formed from peroxide series, oxidized by ozone gas. Peroxide is formed as much as the broken double bonds in unsaturated Ansature oil. The oil should be ozonated until it becomes solid [2]. It is classified according to the amount of ozonoid (peroxide) in ozonated oils. Ozone oil has a long time to stay active when it is stored in the refrigerator and with its mouth closed. Dr J. Hansler has shown that good quality ozone oil will maintain its quality in the refrigerator for more than 10 years [3] (Figure 2).

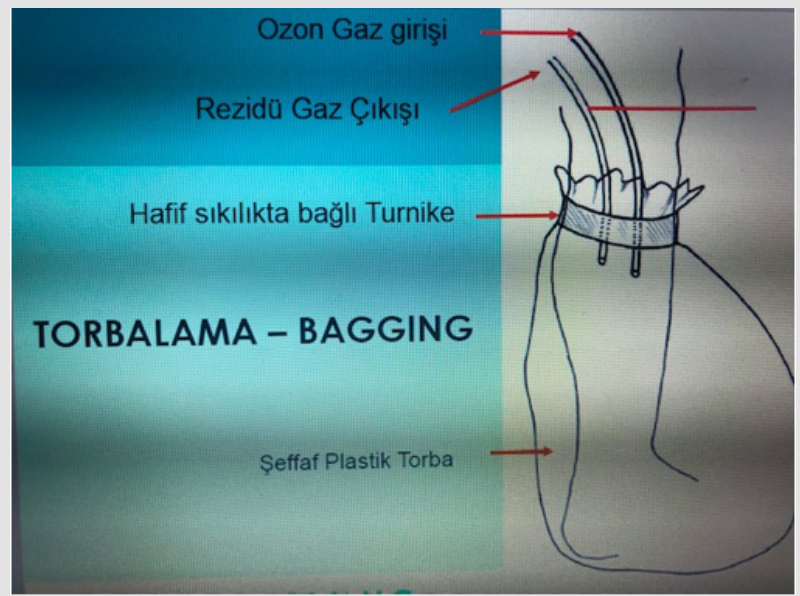

Figure 1: Technic of bagging ozone. Ozone gas entrance, exit, tourniquet, bag. 


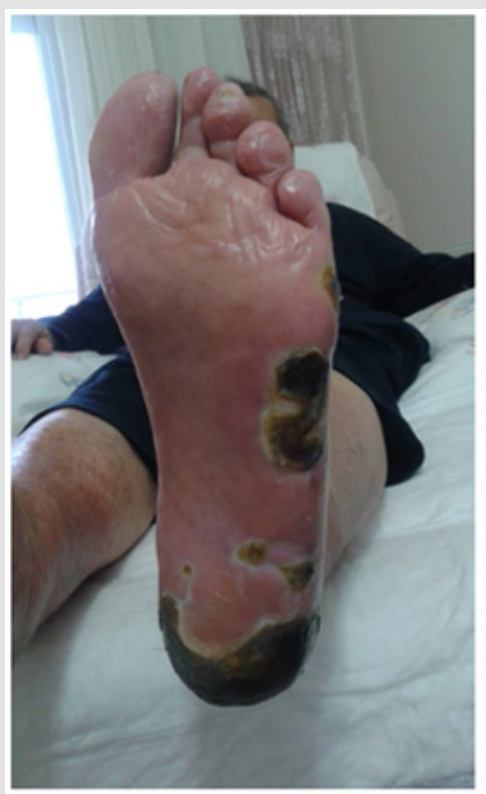

Treatment before

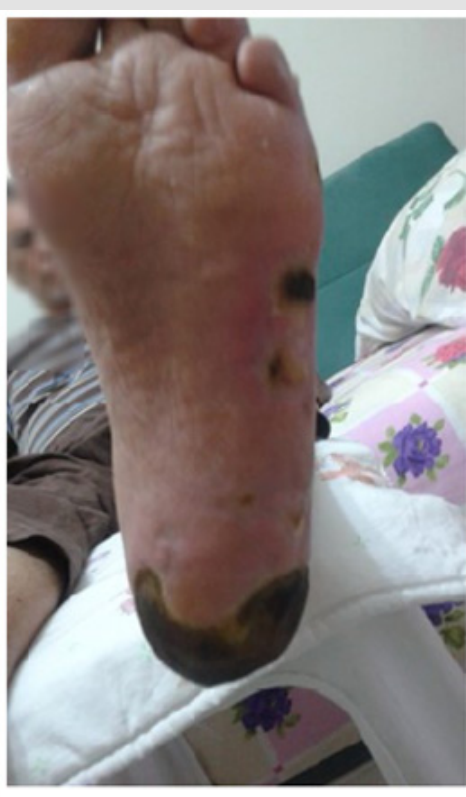

In treatment during

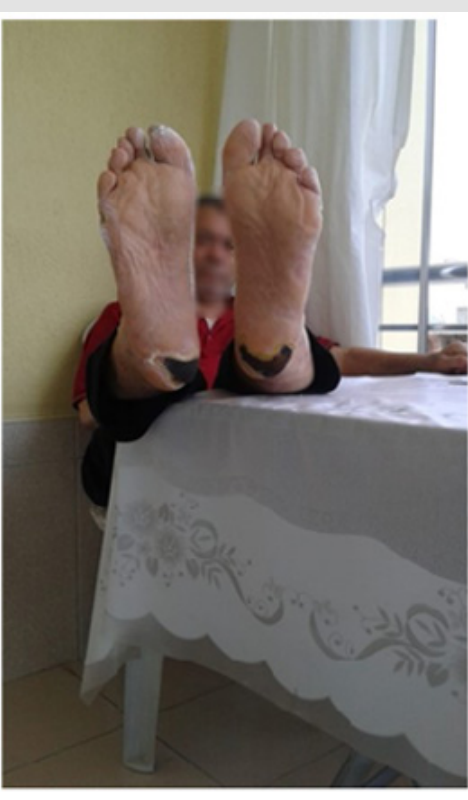

After treatment ozone

Figure 2: Case figures.

Every year peroxide rate is $5 \%$ when stored at $+4{ }^{\circ} \mathrm{C}, 30-50 \%$ when stored at $+20^{\circ} \mathrm{C}$. The mechanism of action of ozone oil provides skin oxygenation, increases microcirculation, triggers tissue repair and regeneration, slows the skin aging process. The omega3,6,9s present in the content of the ozonated oil have anti-inflammatory effects. It reduces fluid loss of the skin. The effects of ozone oil on the healing of the experimental skin flap were investigated. In the acute cutaneous wound healing model, it has been reported that ozone oil contributes to neovascularization. With the study, the effect of ozonized oil on vascular endothelial growth factor has been shown to be positive in rats [4]. It is emphasized that the combination of ozonized oil with $\alpha$-bisabolol (chamomile) is effective in supportive treatment in venous ulcer cases and necrotic wounds [5]. A study was conducted on the experimental facial nerve paralysis of ozone therapy; Ozone therapy has been found to be effective in regeneration of facial nerve damage in rats [6].

\section{Case}

The male patient was 68 years old, and he was diagnosed with antiphospholipid syndrome. While undergoing intensive care treatment for 2-3 months, venous ulcers have formed on his feet. neither applied for ozone therapy. The patient was taking multiple antiaggregants (salicylic acid, corasprin 100, trental cr 600, coumadin $5 \mathrm{mg}$. There was coronary stent 2 times in her anamnesis. He had hemo dialysis treatment for 8 months with inr follow-up. Digoxin $0.0 .25 \mathrm{mg}$, Ator $40 \mathrm{mg}$ for cardiac problems. , desal tb, Beloc $100 \mathrm{mg}$, Diltizem 90mg, ursaactive for gall bladder stone, levotron $0.25 \mathrm{mg}$ for goiter. Antiphosphate capsule $500 \mathrm{mg} 3 \times 1$ and endoxane for Panto tb antiphospholipid syndrome. Permission was obtained from patients or legal representative if required.
First, ozone oil was applied to the ulcer area. Then, beating ozone therapy was performed every 5 days $(20-30-40-60-70 \mu \mathrm{g}$ / $\mathrm{ml}$ doses) every other day. The last patient was asked to apply sarichanone oil. The ulcers in both the heel area and side parts of the geriatric patient using multiple drugs and antiphospholipid syndrome also improved in the 3rd week. The dead skin of the patient was peeled, and new tissue granulated from the bottom was observed.

\section{Discussion}

There are many publications in the literature about the therapeutic properties of ozone. In infected wound treatment study; Staphy in irrigation with ozone saline. The effect of ozone on sterilasation and wound healing, in which the Aureus biofilm layer is removed, has been shown [7]. Usage areas of ozone therapy were determined by Madrid declaration in 2010 [8]. In the studies conducted, the results of multitrauma were very successful with the addition of ozone therapy to the treatment $[9,10]$. The same study group reported that they achieved very successful results in fournier gangrene. Ozone therapy and hyperbaric oxygen therapy have not been shown to be superior to each other in studies performed on different groups of experimental animals. It is stated that both of them increase bone wound healing [11]. Ozone therapy, which is effectively used in bone healing, has been shown to reduce staphylococcal colonization by 99\% within 15 minutes without showing cytotoxic effects to osteoblasts [12]. Ozone therapy has been found to increase the inflammatory neutrophil migration and activate IL-10 via TNF- $\alpha$ [13].

In a randomized controlled gingival deepitelizing graft case study, the postoperative of ozone therapy. It has been determined 
that with the better blood flow in the first week, it improves wound healing, increases quality of life, and decreases pain [14]. Ozone therapy, which was used empirically at the beginning, now finds use in many skin related diseases with a better understanding of its biological effects. Ozone therapy, which is used effectively in tissue healing, has been found effective in all 3 phases of wound healing. It can be used effectively in both gram negative and gram positive bacteria, virus and fungal infections $[15,16]$. The mechanism of action of ozone oil provides skin oxygenation, increases microcirculation, triggers tissue repair and regeneration, slows the skin aging process. The omega3,6,9s present in the content of the ozonated oil have anti-inflammatory effects. It reduces fluid loss of the skin [17]. Also, it is a subject to be kept on the agenda and investigated as an adjuvant treatment method that provides both antimicrobial and tissue regeneration. Although our information about the exact mechanisms of ozone therapy is more recent, it is quite promising especially in skin and mucous diseases.

\section{References}

1. Makita Y, Imamura Y, Masuno K, Tamura I, Fujiwara S, et al. (2015) The effect of ozone on collagen type-1 and inflammatory cytokine production in human gingival fibroblasts. Dentistry 5: 339.

2. Bocci V (2002) A new Drog Ozone Springer Netherlands.

3. Hansler RV, Fernandez OSL, Fahmy Z (2012) Ozone in medicine: lowdose ozone concept-guidline and treatment strategies. Science \& engineering 34(6): 408-424.

4. Krkl C, Yiğit MV, Özercan İH, Aygen E, Gültürk B, et al. (2016) The Effect of Ozonated Olive Oil on Neovascularization in an Experimental Skin Flap Model. Adv Skin Wound Care 29(7): 322-327.

5. Velikaya VV , Gribova OV , Musabaeva LI , Startseva ZhA, Simonov KA, et al. (2017) Ozone therapy for radiation reactions and skin lesions after neutron therapy in patients with malignant tumors. Voprosy Onkologii 61(4): 571-574.

\section{ISSN: 2574-1241}

DOI: 10.26717/BJSTR.2021.33.005432

Hayriye Alp. Biomed J Sci \& Tech Res

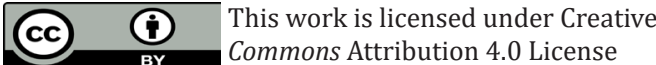

Submission Link: https://biomedres.us/submit-manuscript.php
6. Ozbay I, Ital I, Kucur C, Akcllar R, Deger A, et al. (2017) Effects of ozone therapy on facial nerve regeneration. Braz J Otorhinolaryngol 83(2): 168-175.

7. Al Saadi H, Potapova I, Rochford ETJ, Moriarly TF, Messmer P (2015) Ozonated saline shows activity against planktonic and biofilm growing Staphylococcus aureus in vitro: a potential irrigant for infected wounds. Int Wound Journal 13(5): 936-942.

8. Schwartz A, Guemez FA, Nazarov SEI, Viebahn Haensler R, Rieck AE, et al. (2010) Madrid Declaration on ozone therapy. Madrid.

9. Türkmen A, Kesici S, Keles E, Büyükyıldırım A, Kesici U, et al. (2015) Ozone treatment in patient with multiple traumas 2015. Case study and case reports (5) 1: 25-28.

10. Türkmen A, Kesici S, Keles E, Büyükyıldırım A, Kesici U, et al. (2015) Ozone treatment in patient with multiple traumas 2015. Case study and case reports 5(1): 21-24.

11. Kan B, Secimen M, Bayar GR, Korkusuz P, Coşkun AT, et al. (2015) Histomorphometric and microtomographic evaluation of the effects of hyperbaric oxygen and systemic ozone, used alone and in combination, on calvarial defect healing in rats. Journal Maxillofac Surgery 73(6): 1231.e1-10.

12. Dawley C (2018) Aqueous Ozone Inactivation of Viruses and Bacteria on Biotic and Abiotic Surfaces. Theses and Dissertations.

13. Hao K, Liu Y, Feng J, Zhang W, Zhang Y, et al. (2015) Ozone promotes regeneration by regulating the inflammatory response in zebrafish. Int Immunopharmacol 28(1): 369-375.

14. Taşdemir Z, Alkan BA, Albayrak H (2016) Effects of Ozone Therapy on the Early Healing Period of Deepithelialized Gingival Grafts: A Randomized Placebo-Controlled Clinical Trial. J Periodontol 87(6): 663-671.

15. Zeng J, Lu J (2019) Mechanisms of Action Involved in Ozone-Therapy in Skin Diseases. Int Immunopharmacol 56: 235-241.

16. Vinnik IS, Salmina AB, Tepliakova OV, Drobushevskaia AI, Pozhilenkova EA, et al. (2015) The results of combined ozone therapy using in complex treatment of soft tissues infections in patients with diabetes mellitus type II. Khirurgiia (2): 63-69.

17. Sakai D, Makita Y, Masuno K, Fujiwara S, Okazaki J, et al. (2014) Local hemostatic effect of aqueous ozone in cutting wound surface. J Hard Tissue Biol 23(2): 245-248.

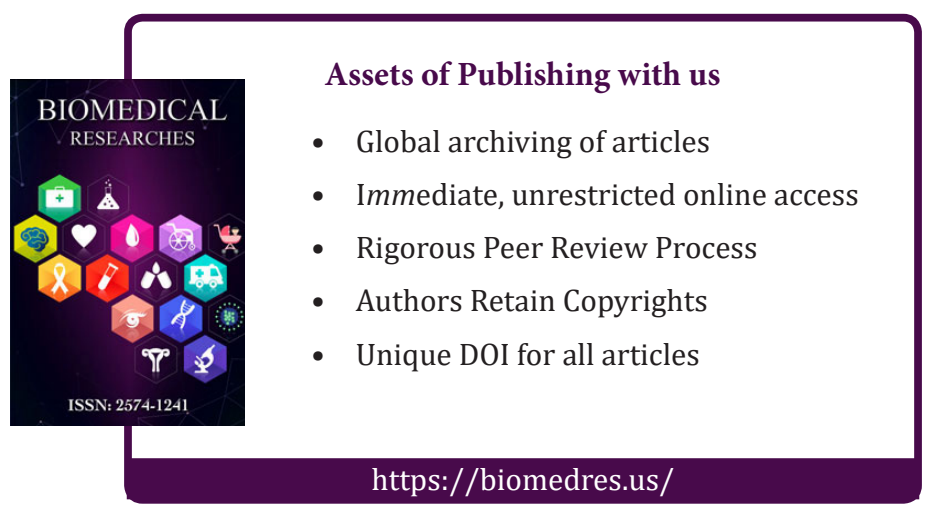

